\title{
Do microplastics affect marine ecosystem productivity?
}

Tineke Troost ${ }^{1 *}$, Térence Desclaux ${ }^{1,2}$, Heather A. Leslie ${ }^{3}$, Myra Van der Meulen ${ }^{1}$, A. Dick Vethaak ${ }^{1,3}$

${ }^{1}$ Deltares, Marine and Coastal Systems, P.O. Box 177, 2600 MH, Delft, The Netherlands

2 Ifremer, Centre de Bretagne, Département DYNECO, CS 10070, 29280 Plouzané, France

${ }^{3}$ Vrije Universiteit, Department of Environment and Health, De Boelelaan 1087, 1081 HV Amsterdam,

The Netherlands

*Corresponding author

Email: tineke.troost@deltares.nl

This is a pre-print version of a paper published in Marine Pollution Bulletin and should be cited as:

Troost, T. A., Desclaux, T., Vethaak, A. D., Leslie, H. A., \& van der Meulen, M. D. (2018). Do microplastics affect marine ecosystem productivity? Marine Pollution Bulletin 135, 17-29.

Link to published version:

https://www.sciencedirect.com/science/article/pii/S0025326X18303965 


\begin{abstract}
Marine and coastal ecosystems are among the largest contributors to the Earth's productivity. Experimental studies have shown negative impacts of microplastics on individual algae or zooplankton organisms. Consequently, primary and secondary productivity may be negatively affected as well. In this study we attempted to estimate the impacts on productivity at ecosystem level based on reported laboratory findings with a modelling approach, using our biogeochemical model for the North Sea (Delft3D-GEM). Although the model predicted that microplastics do not affect the total primary or secondary production of the North Sea as a whole, the spatial patterns of secondary production were altered, showing local changes of $\pm 10 \%$. However, relevant field data on microplastics are scarce, and strong assumptions were required to include the plastic concentrations and their impacts under field conditions into the model. These assumptions reveal the main knowledge gaps that have to be resolved to improve the first estimate above.
\end{abstract}

Keywords: ecosystem productivity; microplastics; modelling approach; Delft3D-GEM; North Sea; zooplankton;

\title{
1 Introduction
}

Marine and coastal ecosystems are among the largest contributors to the Earth's biomass generating capability (Nichols et al., 2010), also known as 'productivity'. We owe this productivity to algae (mainly phytoplankton), which take up dissolved inorganic carbon and turn it into organic carbon. This autotrophic capability makes them the primary producers of the ecosystem and places them at the base of the marine food web. Heterotrophic organisms feeding on algae (e.g. zooplankton) are the secondary producers and form the link between the lower and higher parts of the food web, including fish, birds and marine mammals. In the North Sea, for instance, the larval stages of the wide majority of fish species rely on copepods as feed (Daewel et al., 2014).

Microplastics potentially pose a threat to this important source of the world's biomass. With continuous growth for more than 50 years, global plastic production in 2014 rose to 311 million tonnes (PlasticsEurope, 2015). Yet it has been estimated that annually 6 to $10 \%$ of the global plastic production ends up in the marine environment; without improvement in waste 
management infrastructure, the plastic waste will vastly increase by 2025 (Jambeck et al., 2015).

As plastic debris degrades very slowly, it is of little surprise that this material is now a pervasive and persistent contaminant of the marine environment. An important part of these released plastics may reach microscopic scales, thus forming what is termed 'microplastics', i.e. plastic particles with a maximum size of $5 \mathrm{~mm}$ down to the nanometer scale (Arthur et al., 2009). The microplastic component of the marine litter is of special interest as its small size makes it available for ingestion by a wide range of marine biota (Ivar do Sul and Costa, 2014; GESAMP, 2016). Experimental results indicate that microplastics negatively affect marine algal productivity (e.g. Bhattacharya et al., 2010; Sjollema et al., 2014) and zooplankton health and function, resulting in significantly decreased algal feeding (e.g. Cole et al., 2014).

When experimental results indicate negative impacts of microplastics on the health and fitness of individual organisms or laboratory cultures of algae and zooplankton species, it is difficult to predict how these impacts would manifest themselves at the ecosystem level. An ecosystem can be described as a complex set of interactions among organisms, nutrients and the abiotic environment through which energy flows and nutrients are cycled. Laboratory toxicity experiments typically only focus on a tiny fraction of the organisms and toxic substances involved, which makes it a challenge to scale up their results to the ecosystem level. Another major problem is to understand the ecosystem level impact that results from potentially large spatial and temporal variations in microplastic concentrations and environmental conditions under which the ecosystem operates. Moreover, these variable environments do not exist in isolation, but food or organisms may be diluted or resupplied/recolonised from adjacent water volumes. Marine ecosystem models help to address these issues by capturing essential parts of the complexity necessary to predict impacts at the ecosystem level. The model used in this study includes a simplified but integral food web (i.e. nutrients, four algal species, and zooplankton) as well as full spatial and temporal variability.

The objective of this study was to estimate the impact of microplastics on ecosystemlevel productivity. For this we extended the Delft3D-GEM ecosystem model (Los et al., 2008; Blauw et al., 2009) for the North Sea to include zooplankton on the basis of Dynamic Energy Budget (DEB) theory. DEB-theory is a modelling framework based on first principles and simple physiology-based rules that describe the uptake and use of energy and nutrients 
and the consequences for physiological organisation throughout an organism's lifecycle (Kooijman, 2000). Microplastic concentrations in the Southern North Sea were included by means of a forcing function resulting from a previous modelling study of the transport of microplastics in the North Sea (Van Der Meulen et al., 2016 and 2014; Stuparu et al. 2015; Pope, 2015; also see section 2.2). Impacts of microplastics on relevant process parameters of algae (respiration rate) and zooplankton (caloric ingestion rate) were calibrated based on data from literature and were implemented in the model. With this modified model set-up, various runs were performed and resulting productivities in the Southern North Sea were compared to those of the base model without microplastics. Model set-up and the modifications mentioned above are described in the methods section below. Note that we focus on pelagic productivity only and do not look into benthic productivity.

\section{Methods}

\subsection{Delft3D-GEM for the North Sea}

The biogeochemical transport model Delft3D-GEM is an open-source generic ecological modelling instrument that can be applied to any water system (fresh, transitional or coastal water) to calculate nutrient concentrations (nitrate, ammonium, phosphate, silica), dissolved oxygen and salinity, phytoplankton, and detritus. The Delft3D-GEM as applied to the North Sea is described in Los et al. (2008) and Blauw et al. (2009). It includes nutrients (carbon, nitrogen, phosphorous, silica and oxygen), detritus, four groups of phytoplankton (diatoms, flagellates, dinoflagellates and Phaeocystis) and was extended with a zooplankton compartment in this study. Furthermore, it includes all relevant biogeochemical processes (Fig. 1). The most relevant inputs and processes for this study are described below.

\section{Fig. 1. Diagram of the state variables and processes in the generic ecosystem model (Delft3D-GEM) as extended with zooplankton}

\subsubsection{Model grid}

The modelling grid used in the GEM for the North Sea is called the ZUNO-grid (Fig 2). This grid covers the southern North Sea and the eastern English Channel but we refer to its domain only as the former. The model grid consists of 4350 grid cells in the horizontal and 12 topography-following vertical layers. The grid is curvilinear, with a resolution ranging from $1 \times 1 \mathrm{~km}$ at the continental coast to $20 \times 20 \mathrm{~km}$ at the North-western boundary. In 
addition to the 12 layers in the water column, a single (and relatively thin) sediment layer is taken into account without an explicit benthic community. Validation exercises showed that this single-layer approach for the bottom is capable of capturing the dynamics of the eutrophication-related variables in the Southern North Sea (see section 3.1).

\section{Fig. 2. Model grid of the Delft3D-GEM for the Southern North Sea}

\subsubsection{Hydrodynamics}

Hydrodynamic transports underlying Delft3D-GEM are calculated using Delft3DFLOW (http://oss.deltares.nl/web/opendelft3d), a multi-dimensional 3D hydrodynamic model that calculates non-steady flow and transport phenomena that result from tidal and meteorological forcing, under the Boussinesq approximation, on a rectilinear or a curvilinear boundary-fitted grid. Hydrodynamic process details are described in Deltares (2017), and its set-up for the North Sea Delft3D-GEM is described in Los et al. (2008). Meteorology is included as forcing functions based on measurements. Silt concentrations are included as a forcing function based on a climatology combined with short-term wind-dependent variation.

\subsubsection{Nutrient inputs and boundary conditions}

Nutrients enter the North Sea system via 85 rivers, 2 open boundaries (the Atlantic Ocean and Channel), and via atmospheric deposition. In the model, each river discharges into one coastal grid cell in the surface layer. Discharges and nutrient concentrations for all rivers are based on a database that was set up and maintained by Cefas (pers comm S. van Leeuwen, Centre for Environment, Fisheries and Aquaculture). The Atlantic boundary consists of all segments located on the Northern model interface, the Channel boundary of all segments on the South-western North Sea model interface. Boundary concentrations are included as forcing functions based on in-situ measurements (Channel boundary: Bentley et al., 1999; Bot et al., 1996; Brion et al., 2004; Laane et al., 1993, 1996a; Radach et al., 1996; Atlantic boundary: Bot et al., 1996; Brockmann and Topcu, 2002; Laane et al., 1996b; NERC, 1991; Pätch and Radach, 1997; Radach et al., 1996). Atmospheric deposition of nitrogen takes place over the whole surface layer and is included as a spatially and temporally explicit forcing function. This atmospheric function was based on data in the year 2002 kindly provided by EMEP (European Monitoring and Evaluation Programme under the Convention on Long-range Transboundary Air Pollution). These data are based on results from the Unified EMEP model as reported by Bartnicki and Valiyaveetil (2008). 


\subsubsection{Phytoplankton module}

The phytoplankton module (BLOOM) in Delft3D-GEM simulates primary production, respiration and mortality of phytoplankton. This module allows for the modelling of species competition and adaptation of phytoplankton to limiting nutrients or light (Los, 2005; Los and Bokhorst, 1997; Los and Brinkman, 1988; Los et al., 1994; Van der Molen et al., 1994). For the simulation of species competition, several species (groups) are predefined in BLOOM, four of which are included in the GEM for the North Sea: diatoms, flagellates, dinoflagellates and Phaeocystis. Within each of these groups, three phenotypes are defined to account for adaptation to changing environmental conditions. Growth-related processes are combined with an optimisation technique (linear programming) to determine the algal species and phenotypes composition that are best adapted to prevailing environmental conditions.

\subsubsection{Zooplankton module}

Zooplankton can be defined as the heterotrophic marine planktons, including both herbivorous and omnivorous species. In the North Sea, Pseudocalanus sp. and Calanus finmarchicus and to a smaller extent Paracalanus Parvus, Temora longicornus, Acartia spp., and Centropages typicus copepod species are reported to be dominant regarding zooplankton biomass (Daewel et al., 2014). In its standard set-up for the North Sea, the model does not explicitly include grazing of phytoplankton, but this is implicitly accounted for by constantly elevated mortality rates. In this study we extended the model by including an explicit zooplankton compartment (see Fig. 1) and by reducing the algal mortality rate correspondingly.

Zooplankton biomass was modelled using the grazer module (DEBGRZ), which is available in the DELFT3D water quality process library. The module is based on the Dynamic Energy Budget (DEB) theory and consists of the standard set of DEB equations adjusted to include filter-feeding and spawning-related processes ((as were previously used and described in Bacher \& Gangnery, 2006; Pouvreau et al., 2006; Rosland et al., 2009; Wijsman et al., 2009; Troost et al., 2010). Although the DEB approach may seem relatively complex, it provides several advantages such as genericity and flexibility, and its adherence to thermodynamic principles. Also, its mechanistic description of physiological mechanisms allows for linking of external microplastic concentrations (or any other chemical compounds) to the effects on life-history traits (survival, growth and reproduction) over time. This is one 
of the reasons for its wide use in ecotoxicology (http://www.debtox.info/papers_debtox.html).

The standard DEB equations are expressed at the individual level, while ecosystem models require scaling up to the population level. In this application we used the so-called 'V1-morph' approach to scale the individual growth model up to population level. V1morphs are a specific class of shape-changing organisms that have a constant surface-tovolume ratio (Kooijman, 2000). This requires the additional assumption that the size distribution of the population is constant during the year. In turn, it reduces the number of state variables, which makes the model easier to initialise, calibrate or analyse, and is specifically suitable when only a little information is available about the population size- or age-distribution (as is typically the case for zooplankton).

Most model parameters for zooplankton were based on the parameter values as provided in the 'add my pet' database (http://www.bio.vu.nl/thb/deb/deblab/add my pet/species list.html), consulted in 2014. Since no values were available for the North Sea zooplankton species, we used those of the freshwater copepod Cyclops vicinus, as this was the only copepod parameter set that resulted in a North Sea-wide distribution of the modelled zooplankton. System and populationspecific parameters were based on alternative sources. A full overview is given in Table 2.1.

\subsubsection{Modelled period and spin up}

The modelled period was chosen to be the year 2008 (see section below). Thanks to the single-layer approach for the bottom (see section 2.1.1), bottom concentrations in our model system reach a quasi-steady-state relatively fast, in the order of 1 or 2 simulated years. The standard model run (without zooplankton) is initialised with settings that are the result of a previous series of model runs starting at 1985. For each of the modelled scenarios, including a zooplankton compartment, the model was spun up for an additional year.

\subsection{Modelled plastic concentrations}

Microplastic concentrations were included in the model through a forcing function that varies both spatially and temporally. This function was based on model results from a related modelling study on the abundance and distribution patterns of eight common microplastics in the North Sea (Van Der Meulen et al., 2016 and 2014; Stuparu et al. 2015; Pope, 2015). In that modelling study, an estimated total particle load entering the North Sea 
was distributed over all rivers by the amount of ports, urban areas, and populations that would use each river to discharge their wastewater effluents. The total particle load per year was calibrated on the approximate amount of microplastics entering into the Rhine (51.3 tonnes/year; Van der Wal et al., 2014). According to the calibrated model, the total amount of microplastics per year discharged into the North Sea is 5,900 tonnes. Microplastic particle movement was calculated based on hydrodynamics as well as on various microplastic properties (density, size, and shape; see Table 2.1). Model results were available for the years 2003-2008; we chose the year 2008 because the concentrations in this year were fully spun up.

Though the general trends in horizontal and vertical distribution of microplastics are reflected by the model (Van Der Meulen et al., 2016; Pope, 2015), a thorough validation of the modelled plastic concentrations was not possible because suitable field data are scarce (Van Der Meulen et al., 2016; Pope, 2015; Leslie et al., 2011). Also, the few data available are difficult to compare because of the different sampling nets used (Van Der Meulen et al., 2016). For example, reported concentrations in Swedish coastal water ranged from 150-2400 particles $/ \mathrm{m}^{3}$ with an $80 \mu \mathrm{m}$ mesh size net to 0.01 to 0.04 particles $/ \mathrm{m}^{3}$ with a $450 \mu \mathrm{m}$ mesh size (Norén, 2008). Furthermore, quality assurance for microplastics measurements is still not up to standard, which makes most microplastic measurements hard to pinpoint to within orders of magnitude (Leslie et al., 2011). Moreover, the model results indicate that plastic concentrations in the water column are very variable, emphasising that scarce or single measurements may have a large uncertainty (Van Der Meulen et al., 2016). Finally, it should be realised that measured plastic concentrations have been constantly changing over time along with the ever-changing production, use, and waste of plastics (PlasticsEurope, 2015). Although currently not possible, validation of the modelled plastic concentrations would be a huge step forward in our ability to estimate impacts of microplastics under field conditions.

Table 2.1. Microplastic properties that were included in the particle tracking model of eight common microplastics in the North Sea (after Van Der Meulen et al. 2016), the results of which were used as input to the underlying study

\begin{tabular}{|l|l|l|l|l|l|}
\hline Plastic Name & $\begin{array}{l}\text { Density } \\
\left(\mathbf{k g} / \mathbf{m}^{\mathbf{3}}\right)\end{array}$ & $\begin{array}{l}\text { Shape } \\
\text { Factor }\end{array}$ & Shape & $\begin{array}{l}\text { Mean } \\
\text { Radius } \\
(\mathbf{m m})\end{array}$ & $\begin{array}{l}\text { Variance } \\
\mathbf{( m m )}\end{array}$ \\
\hline $\begin{array}{l}\text { Polyamide } \\
\text { Fibre }\end{array}$ & 1100 & 0.2 & Fibre & 0.1 & $2.50 \mathrm{E}-06$ \\
\hline
\end{tabular}




\begin{tabular}{|l|l|l|l|l|l|}
\hline $\begin{array}{l}\text { Polyethylene } \\
\text { Fragment }\end{array}$ & 930 & 0.5 & Fragment & 0.577 & $2.54 \mathrm{E}-04$ \\
\hline $\begin{array}{l}\text { Polyethylene } \\
\text { Pellet }\end{array}$ & 930 & 1 & Granular & 0.564 & $1.74 \mathrm{E}-04$ \\
\hline $\begin{array}{l}\text { Polypropylene } \\
\text { Fibre }\end{array}$ & 900 & 0.5 & Fibre & 0.630 & $2.58 \mathrm{E}-04$ \\
\hline $\begin{array}{l}\text { Polypropylene } \\
\text { Sphere }\end{array}$ & 900 & 1 & Sphere & 0.875 & $1.56 \mathrm{E}-03$ \\
\hline $\begin{array}{l}\text { Polypropylene } \\
\text { Fragment }\end{array}$ & 900 & 0.7 & Fragment & 0.875 & $1.16 \mathrm{E}-04$ \\
\hline $\begin{array}{l}\text { Polystyrene } \\
\text { Pellet }\end{array}$ & 1040 & 0.9 & Granular & 0.265 & $2.40 \mathrm{E}-04$ \\
\hline $\begin{array}{l}\text { Polyethylene terephthalate } \\
\text { flake }\end{array}$ & 1410 & 0.3 & Flake & 0.66 & $2.50 \mathrm{E}-04$ \\
\hline
\end{tabular}

The mean size of the modelled plastic particles ranged between 0.1 and $0.875 \mathrm{~mm}$ (see Table 2.1), which is much larger than the minimum size for which a significant impact was found on algae under laboratory conditions $(0.5 \mu \mathrm{m}$, Sjollema et al., 2014). This discrepancy arises from the fact that modelled shapes and sizes were based on field data. Size ranges reported in field data are almost always in a larger size range (normally > 285 or >333 micron) due to different types of nets and continuous plankton recorder mesh sizes. Like the larger-sized microplastics, the smaller-sized microparticles may be released directly into the environment but can also be formed through the degradation of larger sized microplastics. Unfortunately, due to methodological challenges, not much is known (yet) about concentrations, sources or fates of particles with dimensions $<10 \mu \mathrm{m}$ in the environment (Koelmans et al., 2015; GESAMP, 2016). To be able to bridge this gap and include impacts of such small microplastic particles in the model, we made the strong ${ }^{3}$ assumption that the local mass concentrations of microplastics in the relevant size range (i.e. $0.05-0.5 \mu \mathrm{m}$ ) is equal to the total mass concentration of all microplastics used in the model approach described above (Van Der Meulen et al., 2016 and 2014; Stuparu et al., 2015; Pope, 2015). More precisely, the forcing function describing microplastic concentrations in the relevant size class over time and space was constructed by summing the modelled mass concentrations $\left(\mathrm{kg} / \mathrm{m}^{3}\right)$ of all (larger-sized) microplastics included in their model per grid cell and time step. The underlying rationale was that larger items and particles break down without losing too much mass. This is due to slow, near-negligible mineralisation rates of the polymer chains-

\footnotetext{
${ }^{3}$ Note that with 'strong assumption' we refer to an assumption that is not well-supported and could thus possibly diverge from reality
} 
the organic chemical additives are typically the first to mineralise and then the mass reduction stalls for decades/centuries. On the one hand, this may lead to overestimations because it does not take into account any degradation that does occur (such as breaking down under the influence of UV-light or after the ingestions by krill (Dawson et al., 2018). On the other hand, it may lead to underestimations since it does not take into account any accumulation over time. Norén and Naustvoll (2011) found that measured particle concentrations increased disproportionally with smaller mesh sizes (also when particle concentrations were converted into units of volume). This suggests that accumulation may be a more dominant process than decay, in which case our assumption will probably lead to an underestimation of the microplastics concentrations in the relevant size range. In line with the original model results (Van Der Meulen et al., 2016 and 2014; Stuparu et al., 2015; Pope, 2015), our forcing function showed that microplastics on the surface follow the prevailing wind and current patterns while the sea floor particles follow bottom shear stress or sink quickly at the input source. Areas of large concentrations of microplastics are generally found along coastlines and deltas, as is also illustrated by the annual average concentration in the upper layer of the model (see Fig 3). Average concentrations in the bottom layer are smaller but follow the same patterns; concentrations in intermediate layers are much smaller (not shown).

\section{Fig 3. Annual average microplastic concentration}

\subsection{Calibration of impact pathways}

The relation between the microplastic concentration and the impact on the primary and secondary producers (phytoplankton and zooplankton) was calibrated by experimental data. We carried out the following steps for both phytoplankton and zooplankton: (1) Selection of the processes and/or parameter(s) that are most probably impacted by plastics; (2) Formulation of the relation between the microplastic concentration and their impact on the selected process/parameter; (3) Calibration of the selected parameter in order to reproduce the biomass loss as observed in controlled experiments under different microplastics concentrations.

\section{Results}

The annual mean primary and secondary production resulting from the Delft3D-GEM model for the North Sea is presented in Fig 4. Both annual productions show similar patterns and are largest along the continental coastlines. 


\section{Fig 4. Annual average productivity in the southern North Sea}

\subsection{Validation results Delft3D-GEM}

Over the past few years, various versions of Delft3D-GEM have been thoroughly and quantitatively validated (Blauw et al., 2009; Los and Blaas, 2010; Los and Wijsman, 2007; Los et al., 2008). Also, an inter-model comparison showed that the model performance (without zooplankton compartment) is in line with that of other biogeochemical flux models of the North Sea, concerning both its behaviour under default conditions and its response to changes (Lenhart et al., 2010). Similarly, an inter-model comparison of the model including zooplankton compartment showed that the average zooplankton biomass and its response to changes in various parameter values are in line with those of other ecosystem models for the North Sea (Maar et al., 2018). Furthermore, we ensured that adding zooplankton to the North Sea model (which was not included in previous model versions) did not lead to a decreased model performance concerning nutrient or chlorophyll concentrations. To this end we compared Taylor diagrams and time series figures from the default model set up with the extended setup. In these diagrams and figures, all 2008 North Sea data from the Dutch national monitoring program (MWTL, https://www.rijkswaterstaat.nl/water/waterdata-enwaterberichtgeving/waterdata) are included.

Taylor diagrams showed that modelled chlorophyll concentrations only change slightly when including an explicit zooplankton compartment in the model (Fig. 5; see Fig. $\mathrm{S} 1$ for the Taylor diagrams of other variables). If anything, spring bloom concentrations slightly increase (Fig. S2). This is probably because in springtime the zooplankton population starts out small and needs some time to increase its grazing pressure, while in the default model run the algal mortality rates are elevated by a constant value to compensate for the absence of zooplankton. Nitrate and phosphate concentrations hardly change (Fig. S3 and S4), ammonium concentrations slightly increase in some locations (Fig. S5). Summer concentrations of silicate increase when including zooplankton in the model (Fig. S6), which decreases the model fit with measurements (Fig. S2). However, the overall model performance remains the same, and primary production is only slightly affected (Fig. S7).

\section{Fig 5. Comparison of model fit with and without including an explicit zooplankton compartment}

\subsection{Impact pathway phytoplankton}




\subsubsection{Selected impact processes and parameters}

Only few published studies are available about the effects of microplastics on algae. Although some documentation is available on the toxicity of some engineered nanoparticles, like oxides, metals, carbon nanotubes or quantum dots on the marine biota and on algae (Andrady 2011), these data cannot be reliably extrapolated to polymer nanoparticles. Yet, it has been demonstrated that smaller polystyrene plastic particles $(<0.5 \mu \mathrm{m})$ can negatively affect the growth of Chlorella and Scenedesmus species of phytoplankton (Besseling et al., 2014; Sjollema et al., 2016; Bhattacharya et al., 2010) and lead to an increase in $\mathrm{CO}_{2}$ concentration as well as in reactive oxygen species (ROS) production (Bhattacharya et al., 2010). Bhattacharya et al. suggested four possible causes for these observations: (I) Adsorbed nanoplastics particles can obstruct the flagella of flagellate species and thus increase respiration to regain motility; (II) Adsorbed nanoplastics particles can obstruct nutrient uptake pathways and $\mathrm{CO}_{2}$ gas flow; (III) The shading effect of adsorbed particles can reduce light input for plankton, thus reducing photosynthetic activity; and (IV) nanoplastics could damage the algal cell walls.

The finding by Bhattacharya et al. (2010) that nanoplastics led to an increased ROS production is in line with hypothesis II: limited gas flow may lead to poor $\mathrm{CO}_{2}$ availability and thus to an imbalance in the photosynthetic electron transport (PET) system. In turn, the resulting increase in ROS may down-regulate the PSII quantum yield (Asada, 2006). However, Sjollema et al. (2016) did not find a significant effect of nanoplastics on photosynthesis efficiency (PSII), which supports neither the gas flow hypothesis (conform II) nor the shading hypothesis (conform III). Hence, in this study, we focus on the hypotheses that the growth reduction is caused by increased motility costs or damage repair (conform I and IV). Both phenomena will lead to an increase in the respiration rate. Hence, in the present study we implement the effects of plastic particles on primary productivity via an increase in the algal respiration rate.

\subsubsection{Calibration results}

First, we quantified the relationship between plastic concentration and algal biomass reduction. Sjollema et al. (2016) observed a $45 \%$ algal growth reduction at plastic concentrations of $250 \mathrm{mg} / \mathrm{l}$ and particles of size $0.05 \mu \mathrm{m}$, while for particles of $0.5 \mu \mathrm{m} \mathrm{a}$ reduction of $10 \%$ was observed; at plastic concentrations of $25 \mathrm{mg} / \mathrm{l}$ no significant impact was found. Furthermore, Sjollema et al. (2016) reported that during the experiment the actual 
plastic concentration was 2-10 times lower than the nominal concentration. These data provide information about the size and slope of microplastics effects, but they do not reveal anything about the shape of the relations. Therefore, three strong assumptions were made, which we kept as simple and straightforward as possible: (i) the relation between the concentration of plastic particles and their impact is linear; (ii) the relation between size of the particles and their impact is linear; and (iii) the plastic particles present in the model runs have an average size in the middle of the relevant range (i.e. $0.25 \mu \mathrm{m}$ ). In other words, the particles have an average impact on algal biomass (i.e. $22.5 \%$ biomass reduction at a plastic concentration of $250 \mathrm{mg} / \mathrm{l}$ and $0 \%$ biomass reduction at $25 \mathrm{mg} / \mathrm{l}$ ). On the basis of these data and assumptions, the relation between plastic concentration $\left[C_{P}\right.$ in $\left.\mathrm{mg} / \mathrm{l}\right]$ and reduction in algal biomass $\left[\Delta \mathrm{C}_{\mathrm{A}}\right.$ in \%] defined as $\Delta \mathrm{C}_{\mathrm{A}}=\alpha \cdot \mathrm{C}_{\mathrm{P}}$ could be derived to have a slope ranging between $\alpha=22.5 /(250 \cdot r)=0.9 \%$ and $0.18 \%$ (for a ratio between actual and nominal concentration of $r=0.1$ and $r=0.5$, respectively).

Second, a relation was established between the respiration rate and the reduction in biomass. To this end, various model test runs with the GEM model for the North Sea were carried out with increasing respiration of algae (ranging from $0-100 \%$ increase). Since we considered the conditions during the spring bloom (from the first of February to the end of March) to be most representative of laboratory conditions (i.e. with environmental conditions and nutrient conditions not limiting growth), we focused on the model results during this period. Results showed a linear relation between an increase in respiration rate [ $\Delta$ resp in \%] and a reduction in algal biomass $\left[\Delta \mathrm{C}_{\mathrm{A}}\right.$ in \%], described by $\Delta \mathrm{C}_{\mathrm{A}}=\beta \cdot \Delta \mathrm{resp}$, with a slope $\beta$ of -0.5 (i.e. for each percentage increase in the respiration rate, the algal biomass is reduced by $0.5 \%)$.

Third, the two equations above were combined, resulting in the following relation between plastic concentration and respiration: $\Delta \operatorname{resp}=\alpha / \beta \cdot \mathrm{C}_{\mathrm{P}}$ with a slope varying between $\alpha / \beta=0.36 \%$ and $1.8 \%$; i.e. for each increase in plastic concentration the maintenance respiration rate increases by a factor of $0.0036-0.018$, depending on the ratio between nominal and actual concentration in the experiment. Since the respiration rate in the model is temperature-dependent, the effect of plastics will have a greater impact at higher temperatures than at lower ones.

\subsection{Impact pathway zooplankton}




\subsubsection{Selected impact processes and parameters}

Most of the impacts of microplastics on marine invertebrates reported in the literature are related to ingestion, reduced food intake and reduction of available energy. In fact, ingestion of plastic particles has been reported to occur for a wide range of organisms, ranging from microzooplankton to mesozooplankton through benthic scavengers as well as deposit feeders and suspension feeders (GESAMP, 2016). Zooplankton are reported to ingest particles up to $30 \mu \mathrm{m}$, and ingestion rates decrease with increasing particle size (Cole et al., 2013). Microplastics ingestion may lead to the accumulation of microplastic particles in the digestive tract, translocation of particles into the circulatory system, and increased immune function costs (Wright et al., 2013). Besseling et al. (2014) showed that the chronic presence of nanopolystyrene was not lethal but could negatively impact reproduction of Daphnia magna. Watts et al. (2016) reported effects on ion exchange and oxygen consumption in shore crabs exposed to polystyrene microspheres $(8 \mu \mathrm{m})$ with different surface coatings. For a range of zooplankton species common to the northeast Atlantic, ingestion of microplastics is reported to reduce the feeding rate (Cole et al., 2013). Furthermore, Cole et al. (2013) reported adherence of microplastics on external appendages, probably inducing extra costs for swimming or difficulties in prey recognition (Cole et al., 2013; Watts et al. 2016).

In the present modelling exercise, we focus on the reduced feeding rate of zooplankton due to ingestion of microplastics observed by Cole et al. (2013) on northeast Atlantic zooplankton. The negative impact of microplastics on feeding rate was implemented in the model by introducing the following relationship between the concentration of microplastics $\left[\mathrm{C}_{\mathrm{P}}\right.$ in $\left.\mathrm{mg} / \mathrm{l}\right]$ and the half saturation constant for food intake $[\mathrm{Xk}$ in $\mathrm{mg} / \mathrm{l}]: \mathrm{Xk}=$ $\mathrm{Xk}_{0}\left(1+\mathrm{C}_{\mathrm{P}} / \mathrm{Yk}\right)$, where $\mathrm{Xk}_{0}$ is the half saturation constant unaffected by plastic particles and $\mathrm{Yk}[\mathrm{mg} / \mathrm{l}]$ is plastic particles concentration-dependent impact. This relationship is analogous to that of the negative impacts of inorganic matter used by Kooijman (2006).

\subsubsection{Calibration results}

The concentration-dependent impact (Yk) was calibrated using data from Cole et al. (2013). Cole (2013) provides food ingestion rates for different concentrations of polystyrene spheres in the size range 7.3-30.6 $\mu \mathrm{m}$. By converting the units of plastic particles from particles/l into $\mathrm{mg} / \mathrm{l}$ (4000 polystyrene particles/l roughly equals $0.86 \mathrm{mg} / \mathrm{l}$ ), the concentration-dependent impact $(\mathrm{Yk})$ could be derived by using least square regression. Note that here the strong assumption was made that the impact was independent of the size of the 
particles. Also note that in Cole's experiment $\mathrm{Yk}$ depends on the algal concentrations following an exponentially decreasing function. Algal concentrations that are twice the halfsaturation constant (as estimated on the basis of pers. comm. Cole, 2014) lead to a value of $\mathrm{Yk}=0.3 \mathrm{mg} / \mathrm{l}$.

\subsection{Modelled impact on primary production}

When taking into account the effects of plastic concentrations on the algal respiration rate, while assuming a worst-case ratio between the actual and nominal plastic concentration $(r=0.10)$ applied in the experiment in Sjollema et al. (2014), model results did not show any effects on annual primary production. Difference plots between these results and those of the reference case only show 'random noise' (i.e. relative differences with a magnitude $< \pm 1 \%$ with a seemingly random spatial distribution, not shown here). Significant negative effects on the modelled primary productivity begin to appear only when multiplying the impact coefficients by ten, which is equivalent to making the assumption that the nanoplastic mass concentration was 10 times higher than the mass concentration of all microplastics, or that their size is closer to $0.05 \mu \mathrm{m}$ than $0.25 \mu \mathrm{m}$, or that the ratio between actual and nominal concentrations would be $r=0.01$ (which is a factor 10 smaller than the worst case estimation by Sjollema et al., 2014). But, even then, relative reductions in primary productivity of more than 1 or $2 \%$ occur only very locally, most of which are located close to the river mouths (Fig. 6).

Fig. 6. Modelled impact of microplastics on primary production

\subsection{Modelled impact on secondary production}

Figure 7 shows the predicted plastic-induced changes expressed in (A) absolute units $\left[\mathrm{gC} / \mathrm{m}^{2} / \mathrm{d}\right]$ and (B) relative units that express the local impact as a fraction of the local secondary production [-]. In absolute terms, the impacts are generally small (0-0.0025 $\left.\mathrm{gC} / \mathrm{m}^{2} / \mathrm{d}\right)$. The largest absolute impacts are mainly found along the coastlines, thus coinciding with areas of higher average productivity and higher plastic concentrations. In relative terms too, impacts are small (at most $\pm 1 \%$ ) in most cells of the grid area. In the northwestern offshore region, however, relative changes in secondary production range up locally to $\pm 10 \%$.

\section{Fig. 7. Modelled impact of microplastics on secondary productivity}

\section{Discussion}


Published experimental results indicate negative impacts of microplastic particles $(<5$ $\mathrm{mm}$ ) on lab-cultured algae or zooplankton organisms. In the present modelling exercise these experimental data were used to estimate the effect of microplastics on pelagic ecosystem productivity. The model results do provide a first estimate of the impacts as well as insight into the underlying North Sea systems' ecological and hydrodynamic processes that act to either protect or threaten ecosystems exposed to microplastic contamination. However, only a few data were available, which greatly hampered model set up, calibration and validation. In fact, various strong assumptions were required to include the plastic concentrations and their impact under field conditions into the model. Obviously, this negatively affects the accuracy and precision of the model results, which should thus be considered with care. Because of the many unknowns, it is not even possible to say whether the results are in the correct order of magnitude or whether they are under- or overestimations. Still, we consider our model study to be a valuable exercise, if only because it reveals the main knowledge gaps and uncertainties that have to be resolved to come to a better estimate. Below, the calculated impacts, the assumptions made and the corresponding knowledge gaps are discussed in more detail.

\subsection{Impact on primary production}

Our model results suggest that, at the microplastic concentrations used in this study (see Fig. 3), microplastics would not significantly reduce the algal biomass and primary productivity in the southern North Sea (Fig. 6). This is mainly because the (relatively high) microplastic concentration of $25 \mathrm{mg} / \mathrm{l}$ that caused significant growth reduction in algae in Sjollema et al. (2016) occurs only in very few modelled areas of the southern North Sea $(<0.05 \%$ of all model segments), all of which are located at a river mouth. On the other hand, it should be kept in mind that microplastic concentrations in the marine environment are expected to further increase in the coming decades (Jambeck et al., 2015).

A second explanation for the lack of modelled impact of microplastics on algae may lie in the environmental variability. Enhanced respiration rates act to reduce the algal maximum (i.e. potential) net growth rates. However, this maximum growth rate is reached only during periods when light and nutrients do not limit algal growth. In the North Sea, these are periods in the exponential growth phase which mainly occur in a relatively short period during the spring bloom. The reduction of the maximum net growth rate is relevant only in these periods. On the other hand, increased respiration rates will also increase the critical light intensity under which phytoplankton growth just balances its losses. This impact is 
relevant under sub-optimal light conditions which, for example, occur in coastal areas with high turbidity or in deeper areas. While former conditions (i.e. non-limiting light and nutrients) coincide with those in laboratory experiments, latter conditions (sub-optimal light conditions) do not. As was found when calibrating the impact of plastic on the respiration rate, the relation between respiration rate and algal biomass (as derived from model results) depended on the period in question: during the spring bloom a doubling in the respiration rate led to a more substantial reduction in the algal biomass (48\%) than when the whole year was considered (19\%). These results illustrate the importance of environmental conditions on the impact of plastic particles. Experimental tests under a range of nutrient and light availabilities could help to validate the assumptions on impact pathways made in the modelling study.

Another factor possibly at play in protecting primary production from harm is the advective transport that may dilute or recolonise the local algal population from adjacent water volumes, dampening the propagation or accumulation of effects of microplastics throughout space or time. In the largely nutrient-limited southern North Sea, this also implies that, when plastics reduce algal growth in one location, un-used nutrients may be transported and used in another location or at another moment, thus regaining overall production.

\subsection{Impact on secondary production}

Our model results indicate that, in large parts of the southern North Sea, impacts of microplastics on secondary production are small, both in relative and absolute terms. In some areas, however, the relative changes range up to $\pm 10 \%$ (Fig. 7B). Yet, since these changes are both positive and negative, they compensate each other, keeping the total impact over the whole North Sea small. These results thus indicate that the main impact of microplastic exposure are changes of the spatial patterns of marine secondary production.

Surprisingly, the areas with the most significant relative impacts are not those with the highest plastic concentrations. In fact, along the continental coastline, the reduction in secondary production is minimal $(<1 \%)$, apart from in a few small areas very close to the river mouths where plastic concentrations are at their maximum. The finding that relative impacts are most prominent in the offshore areas can be explained by the small algal concentrations in those areas. These algal concentrations are closer to the half-saturation rate of the zooplankton, which makes the zooplankton more sensitive to any (plastic- or otherwise induced) change in this parameter. 
This study focuses on pelagic productivity and does not consider impacts on benthic secondary productivity. The underlying rationale is that only a small part of the primary production ever reaches the bottom to become available for benthic secondary production. Most primary production takes place in the upper part of the water column and is consumed there or mineralised into inorganic material. The decay rate of organic material $\left(\sim 0.05 \mathrm{day}^{-1}\right.$ at $10{ }^{\circ} \mathrm{C}$ ) is greater than the travelling time from sea surface to seabed: using a typical sedimentation rate for organic material of 1.5 mday $^{-1}$ and an average depth of the water column in the modelled North Sea domain of $70 \mathrm{~m}$, it can be calculated that $90 \%$ of the organic matter is mineralised before it reaches the bottom. The remaining fraction typically is of a slow decaying type and, therefore, contributes even less regarding productivity. At smaller water column depths, where most phytoplankton and detritus occur, the mineralised fraction will be smaller due to shorter travelling times, but that effect will be partly counteracted by resuspension. On the whole, at least according to our model results, $31 \%$ of the living algae are consumed by secondary producers, and $82 \%$ of the dead organic matter is remineralised in the water column. Net sedimentation of living algae to the bottom constitutes only $2.7 \%$ of the total primary production. Hence only $15 \%$ of all produced material ends up at the bottom and becomes available for benthic secondary production.

On the other hand, plastic particles may accumulate in the sediment, leading to relatively high exposure concentrations (e.g. Leslie et al., 2017). As a result, relative impacts on benthic production may thus be larger than those on the pelagic. To quantify these impacts, more information is required on the settling, resuspension and burial of plastics in the sediment, as well as on the ingestion of plastics by benthic grazers and the relevant impact-pathways (e.g. Wright et al., 2013).

\subsection{Knowledge gaps}

The greatest uncertainty encountered in this study is related to plastic concentrations in the water column itself. Although the plastic concentrations used in the model were based on model results from a dedicated modelling study (Van Der Meulen et al., 2016 and 2014; Stuparu et al. 2015; Pope, 2015), these results had not been validated because suitable data are scarce (see section 2.2). Also, the modelled plastic concentrations only considered plastic particles with a mean radius of $0.1-0.875 \mathrm{~mm}$. Even the smallest particles are thus more than a factor 100 larger than the minimum size for which a significant impact was found on algae (0.5 $\mu \mathrm{m}$, Sjollema et al., 2016). Also, they are a factor 3 larger than the largest particles (30.6 
$\mu \mathrm{m})$ used by Cole et al. (2013) in his experiments to determine their impact on zooplankton. To bridge this gap strong assumptions were required, considering the concentrations of plastic particles in the relevant size range (see section 2.2) and their size-distribution (see section 3.2.2).

Another major uncertainty in this study is formed by the impact pathways of plastic particles on algae or zooplankton. Here, strong assumptions were required to cover the dependencies with particle size and concentration (see sections 3.2.2 and 3.3.2). Note that, in the present study, only two plastic-induced impact pathways were considered (i.e. reduction of the algal respiration rate and zooplankton ingestion rate), while dependencies of impact on shape, charge, or biological species were not taken into account. Obviously, shifts in community composition can be expected when species-specific effects of plastic are taken into account as well. Similarly, age-, size- or stage-specific effects on algae and zooplankton may lead to shifts in their corresponding class distributions, thus further increasing the impact of plastics.

Finally, it is difficult to determine whether, or to what extent, the predicted impacts on primary and secondary production will be felt at higher trophic levels. Although net productivity of the North Sea as a whole may be unaffected, the predicted spatial shifts in secondary productivity or the (potential) shifts in size, age or species class may lead to the disappearance of sensitive species higher up the food web, which may eventually affect fisheries or other ecosystem services. To this end, more research is required involving higher trophic models on food web interactions (e.g. OSMOSE [Shin and Cury, 2001], Ecopath with Ecosim [EwE]) (Christensen and Walters, 2004). Another impact pathway that was not considered in this study is 'trophic transfer': as the ingested plastic particles can be transported through trophic webs (Murray et Cowie, 2013), they also have the potential to exert direct pressure on higher trophic levels. Therefore, research involving bioaccumulation and trophic transfer mechanisms (e.g. Gobas and Arnot, 2010; Bodiguel et al., 2009) deserves more attention as well.

\section{Acknowledgements}


This work was supported by the European Union Seventh Framework Programme (FP7/2007-2013) under grant agreement No. 308370. The contents of this publication are the sole responsibility of the CleanSea Project and can in no way be regarded as reflecting the views of the European Union. Its objectives were to break interdisciplinary barriers and to monitor, understand and predict the pollutions caused by the marine litter and its effects on the environment and provide data, instruments, tools and policy options that would help the EU achieve Good Environment Status for marine litter.

\section{References}

Andrady, A. L. (2011). Microplastics in the marine environment. Mar. Pollut. Bull. 62(8), 1596605. http://doi.org/10.1016/j.marpolbul.2011.05.030

Arthur, C., Baker, J. eds. (2009). Workshop Report on the Occurrence, Effects, and Fate of Microplastic Marine Debris, (January).

Asada, K. (2006). Production and scavenging of reactive oxygen species in chloroplasts and their functions. Plant Physiology, 141(2), 391-396. http://doi.org/10.1104/pp.106.082040

Bartnicki, J., Valiyaveetil, S. (2008). Atmospheric Deposition of nitrogen to OSPAR Con- vention waters in the period 1995-2006. Summary Report for OSPAR Convention. Norwegian Meteorological Institute, Oslo, Norway.

Bentley, Hart, V., Guary,J.C., Statham, P.J. (1999). Dissolved nutrient distributions in the Central English Channel. Cont. Shelf Res. 19, 2083-2099.

Besseling, E., Wang, B., Koelmans, A.A. (2104). Ecotoxic Effects of Nano Plastic on Freshwater Plankton (Scenedesmus Obliquus and Daphnia Magna)." In Book of Abstracts of the International workshop 'Fate and impact of microplastics in marine ecosystems' (pp. 40-40).

Bhattacharya, P., Lin, S., Turner, J.P., Ke, P.C. (2010). Physical adsorption of charged plastic nanoparticles affects algal photosynthesis. 16556-16561.

Blauw, A.N., Los, H.F.J., Bokhorst, M., Erftemeijer, P.L.A. (2009). GEM: A generic ecological model for estuaries and coastal waters. Hydrobiologia, 618(1), 175-198. http://doi.org/10.1007/s10750-008-9575-x

Bodiguel, X., Maury, O., Mellon-Duval, C., Roupsard, F., Le Guellec, A. M., Loizeau, V. (2009). A dynamic and mechanistic model of PCB bioaccumulation in the European hake (Merluccius 
merluccius). Journal of Sea Research, 62(2-3), 124-134.

http://doi.org/10.1016/i.seares.2009.02.006

Bot, P.V.M., van Raaphorst, W., Batten, S., Laane, R., Philippart, K., Radach, G., Frohse, A., Schultz, H., Van den Eynde, D., Clijn, F. (1996). Comparison of changes in the annual variability of the seasonal cycles of chlorophyll, nutrients and zooplankton at eight locations on the north-west European shelf (1960-1994). Dtsch. Hydrogr. Z. 48, 349-363.

Brion, N., Bayens, W., De Galan, S., Elskens, M., Laane, R.W.P.M. (2004). The North Sea: source or sink for nitrogen and phosphorous to the Atlantic Ocean? Biogeochemistry, 68. Springer, pp. 277-296.

Brockmann, U., Topcu, D.H. (2002). Phytoplankton in the Marsdiep at the end of the 20th century; 30 years monitoring biomass, primary production, and Phaeocystis blooms. J. Sea Res. 48, 97-110.

Cole, M., Lindeque, P., Halsband, C., Galloway, T. S. (2011). Microplastics as contaminants in the marine environment: a review. Marine Pollution Bulletin, 62(12), 2588-97. http://doi.org/10.1016/j.marpolbul.2011.09.025

Cole, M., Lindeque, P., Fileman, E., Halsband, C., Goodhead, R., Moger, J., Galloway, T.S. (2013). Microplastic ingestion by zooplankton. Environ. Sci. Technol. 47(12), 6646-6655.

Daewel, U., Hjøllo, S.S., Huret, M., Ji, R., Maar, M., Niiranen, S., Travers-Trolet, M., Peck, M.A. and van de Wolfshaar, K.E. (2014). Predation control of zooplankton dynamics: a review of observations and models. ICES Journal of Marine Science: Journal du Conseil, 71(2), 254271.

Dawson, A.L., Kawaguchi, S., King, C.K., Townsend, K.A. King, R., Huston, W.M., Bengston Nash, S.M. (2018). Turning microplastics into nanoplastics through digestive fragmentation by Antarctic krill. Nature Communications 9.

Deltares, 2017. Delft3D-FLOW users' manual; Simulation of multi-dimensional hydrodynamic flows and transport phenomena, including sediments. Version: 3.15, Deltares, Delft, The Netherlands

Gigault, J., Pedrono, B., Maxit, B., \& Ter Halle, A. (2016). Marine plastic litter: the unanalyzed nano-fraction. Environmental Science: Nano, 3(2), 346-350.

Gobas, F.A.P.C., Arnot, J.A. (2010). Food web bioaccumulation model for polychlorinated biphenyls in San Francisco Bay, California, USA. Environmental Toxicology and Chemistry, 29(6), 1385-1395. http://doi.org/10.1002/etc.164

Ivar do Sul, J., Costa, M.F. (2014). The present and future of microplastic pollution in the marine environment. Environmental Pollution (Barking, Essex : 1987), 185, 352-64.

http://doi.org/10.1016/j.envpol.2013.10.036 
Jambeck, J.R., Geyer, R., Wilcox, C., Siegler, T.R., Perryman, M., Andrady, A., Narayan, R. and Law, K.L., 2015. Plastic waste inputs from land into the ocean. Science, 347(6223), pp.768-771.

Koelmans, A.A., Besseling, E. and Shim, W.J. (2015). Nanoplastics in the aquatic environment. Critical review. In Marine anthropogenic litter (pp. 325-340). Springer International Publishing.

Kooijman, S.A.L.M. (2000). Dynamic Energy Budget Theory for Metabolic Organization (3rd Edition). 3rd edition. Cambridge University Press.

Kooijman, S.L.M. (2006). Pseudo-faeces production in bivalves. Journal of Sea Research, 56, 103-106. http://doi.org/10.1016/j.seares.2006.03.003

Laane, R.W.P.M., Groeneveld, G., De Vries, A., van Bennekom, J., Sydown, S. (1993). Nutreints (P, $\mathrm{N}, \mathrm{Si}$ ) in the Channel and the Dover Strait: Seasonal and year-to- year variation and fluxes to the North Sea. Oceanol. Acta Paris 16, 607-616.

Laane, R.W.P.M., Southward, A.J., Slinn, D.J., Allen, J., Groeneveld, G., De Vries, A. (1996a). Changes and causes of variability in salinity and dissolved inorganic phosphate in the Irish Sea, English Channel, and Dutch coastal zone. ICES J. Mar. Sci. 53, 933-944.

Laane, R.W.P.M., Svendsen, E., Radach, G., Groeneveld, G., damm, P., Pätch, J., Danielssen, D., Foeyn, L., Skogen, M., Ostrowski, M. (1996b). Variability in fluxes of nutrients (N,P,Si) into the North Sea from the Atlantic Ocean and Skagerak caused by variability in water flow. Dtsch. Hydrogr. Z. Hamburg 48, 401-419.

Leslie, H.A., Brandsma, S.H., van Velzen, M.J.M. and Vethaak, A.D. (2017). Microplastics en route: Field measurements in the Dutch river delta and Amsterdam canals, wastewater treatment plants, North Sea sediments and biota. Environ. Internat. 101, 133-142.

Los, F.J. (2005). An Algal Biomass Prediction Model. In: Loucks, D.P., Van Beek, E. (Eds.), UNESCO, pp. 408-416.

Los, F.J., Blaas, M. (2010). Complexity, accuracy and practical applicability of different biogeochemical model versions. J. Mar. Syst. 81, 44-74.

Los, F.J., Bokhorst, M. (1997). Trend analysis Dutch coastal zone. New challenges for North Sea research, Zentrum fur Meeres- und Klimaforschung. University of Hamburg, pp. 161-175.

Los, F.J., Brinkman, J.J. (1988). Phytoplankton modelling by means of optimization: a 10-year experience with BLOOM II. Verhandlungen der Internationalen Vereinigung für Theoretische und Angewandte Limnologie 23, 790-795.

Los, F.J., Villars, M.T., Ouboter, M.R.L. (1994). Model validation study DBS in networks. WL Delft Hydraulics, Delft. 
Los, F. J., Villars, M. T., Van der Tol, M. W. M. (2008). A 3-dimensional primary production model (BLOOM/GEM) and its applications to the (southern) North Sea (coupled physicalchemical-ecological model). Journal of Marine Systems, 74(1-2), 259-294. http://doi.org/10.1016/j.jmarsys.2008.01.002

Lenhart, H.J., Mills, D.K., Baretta-Bekker, H., van Leeuwen, S.M., van der Molen, J., Baretta, J.W., Blaas, M., Desmit, X., Kühn, W., Lacroix, G., Los, H.J., Ménesguen, A., Neves, R., Proctor, R., Ruardij, P., Skogen, M.D., Vanhoutte-Brunier, A., Villars, M.T., Wakelin, S.L. (2010). Predicting the consequences of nutrient reduction on the eutrophication status of the North Sea. J. Mar. Syst. 81, 148-170.

Leslie, H. A.; van der Meulen, M. D.; Kleissen, F. M.; Vethaak, A. D. (2011). Microplastic Litter in the Dutch Marine Environment Providing facts and analysis for with marine microplastic litter. Deltares, 104. http://doi.org/1203772-000Los, F.J.,Wijsman, J. (2007). Application of a validated primary productionmodel (BLOOM) as a screening tool for marine, coastal and transitional waters. J. Mar. Syst. 64, 201-215.

Maar, M., Butenschon, M., Daewel, U., Eggert, A., Fan, W., Hjøllo, S.S., Hufnagl, M., Huret, M., Ji, R., Lacroix, G., Peck, M.A., Radtke, H., Sailley, S., Sinerchia, M., Skogen, M.D., Travers-Trolet, M., Troost, T.A., Van de Wolfshaar, K.. (2018). Lower trophic level complexity mediates responses to top-down 1 forcing: Insights from a comparative modelling approach. Ecological Modelling 376, 54-67.

Mattsson, K., Hansson, L.A. and Cedervall, T. (2015). Nano-plastics in the aquatic environment. Environmental Science: Processes \& Impacts, 17(10), 1712-1721.

F. Murray, P.R. Cowie, Plastic contamination in the decapod crustacean Nephrops norvegicus (Linnaeus, 1758), Marine Pollution Bulletin, 62 (2011), pp. 1207-1217

National Environment Research Council (NERC) (1991). Marine dataset.

Nichols, W.J., Seminoff, J.A., Etnoyer, P. (2010). Biodiversity, function, and interconnectedness: a revolution in our understanding of marine ecosystems and ocean conservation. In: Grafton, Q., et al. (Eds.), Handbook of Marine Fisheries. Oxford University Press, p. 49.

Pätch, J., Radach, G. (1997). Long-term simulation of the eutrophication of the North Sea: temporal developments of nutrients, chlorophyll and primary production in com- parison to observations. J. Sea Res. 38, 275-310.

PlasticsEurope (2015). Plastics - The Facts 2015. http://www.plasticseurope.org/Document/plastics---the-facts-2015.aspx?

Pope, L. (2015). Validation and Analysis of the CleanSea Microplastic Model. Master thesis report; University of Nice and Polytechnic University of Catalonia; p. 98. 
Radach, G., Gekeler, J., Becker, G., Bot, P., Castaing, P., Colijn, F., Damm, P., Danielssen, D., FØyn, L., Gamble, J., Laane, R., Mommaerts, J.P., Nehring, D., Pegler, K., Van Raaphorts, W., Wilson, J. (1996). The NOWESP research data base. Dtsch. Hydrogr. Z. 48 (3-4), 241-259.

Setälä, O., Fleming-Lehtinen, V., \& Lehtiniemi, M. (2014). Ingestion and transfer of microplastics in the planktonic food web. Environmental Pollution (Barking, Essex : 1987), 185, 77-83. http://doi.org/10.1016/j.envpol.2013.10.013

Sjollema, S.B., Redondo-Hasselerharm, P., Leslie, H. A., Kraak, M.H., Vethaak, A.D. (2016). Do plastic particles affect microalgal photosynthesis and growth? Aquatic Toxicology, 170, 259-261.

Sousa, T., Domingos, T., Kooijman, S.L.M. (2008). From empirical patterns to theory: a formal metabolic theory of life. Philosophical Transactions of the Royal Society of London. Series B, Biological Sciences, 363(1502), 2453-2464. http://doi.org/10.1098/rstb.2007.2230

Stuparu, D., Van der Meulen, M., Kleissen, F., Vethaak, D., El Serafy, G. (2015). Developing a transport model for plastic distribution in the North Sea. E-proceedings of the 36th IAHR World Congress, 28 June - 3 July, 2015, The Hague, the Netherlands.

Van der Meulen, M.D., DeVriese, L., Lee, J., Maes, T., Van Dalfsen, J.A., Huvet, A., Soudant, P., Robbens, J., Vethaak, A.D. (2014). Socio-economic impact of microplastics in the 2 Seas, Channel and France Manche Region: an initial risk assessment. MICRO Interreg project Iva

Van Der Meulen, M., Vergouwen, S., Stuparu, D. E., \& de Kluijver, A. (2016). Indicator development for microplastics on the Dutch Continental Shelf. Deltares report 1230100000-ZKS-0004.

Van der Molen, D.T., Los, F.J., Van Ballegooijen, L., Van der Vat, M.P. (1994). Mathematical modelling as a tool for manage- ment in eutrophication control of shallow lakes. Hydrobiologia 275/276, 479-492.

Watts A.J.R., Urbina M.A. Goodhead R., Moger J., Lewis C., and Galloway T.S. (2016). Effect of Microplastic on the Gills of the Shore Crab Carcinus maenas. Environ Sci Technol 50 (10), 5364-5369.

Wright, S.L., Rowe, D., Thompson, R. C., Galloway, T.S. (2013). Microplastic ingestion decreases energy reserves in marine worms. Current Biology : CB, 23(23), R1031-3. http://doi.org/10.1016/j.cub.2013.10.068

Wright, S.L., Thompson, R.C., Galloway, T.S. (2013). The Physical Impacts of microplastics on marine organisms: a review. Environ. Pollut. 178, 483-92.

doi:10.1016/j.envpol.2013.02.031 
Table 1. Parameter descriptions, values and sources as used for the zooplankton module DEBGRZ (in alphabetical order)

\begin{tabular}{|c|c|c|c|c|}
\hline $\begin{array}{l}\text { Parameter } \\
\text { symbol in } \\
\text { DEBGRZ }\end{array}$ & Parameter name & Value & Unit & Ref \\
\hline 'AE_g1' & $\begin{array}{l}\text { digestion efficiency of food to } \\
\text { reserve }\end{array}$ & 0.8 & - & C. vicinus from Add my Pet database \\
\hline 'c_cm3_C_g1' & Conversion from $\mathrm{cm} 3$ to biomass & 0.048 & $\mathrm{gC} / \mathrm{cm}^{3}$ & $\begin{array}{l}\text { C. vicinus from Add my Pet database } \\
\text { (derived from the volume-specific } \\
\text { structural mass) }\end{array}$ \\
\hline 'c_J_gC_zoop' & $\begin{array}{l}\text { Conversion from J to gC for } \\
\text { zooplankton }\end{array}$ & $1.81 \mathrm{E}-05$ & $\mathrm{gC} / \mathrm{J}$ & $\begin{array}{l}\text { C. Vicinus from Add my Pet } \\
\text { database (derived from the } \\
\text { zooplankton specific energy } \\
\text { content) }\end{array}$ \\
\hline 'Eg_L3_g1' & specific cost for structure & 3173 & $\mathrm{~J} / \mathrm{cm}^{3}$ & C. vicinus from Add my Pet database \\
\hline 'Em_L3_g1' & reserve capacity & 3347 & $\mathrm{~J} / \mathrm{cm}^{3}$ & C. vicinus from Add my Pet database \\
\hline 'fmorA_g1' & Fishing/harvesting mortality coef & 0 & - & $\begin{array}{l}\text { No zooplankton harvesting } \\
\text { assumed (i.e. no biomass } \\
\text { extraction from the system) }\end{array}$ \\
\hline 'GSI_upr_g1' & gonado-somatic index & 0.093 & $\mathrm{~mol} / \mathrm{mol}$ & C. vicinus from Add my Pet database \\
\hline 'JXm_L2_g1' & max surface-spec feeding rate & 58.5 & $\mathrm{~J} / \mathrm{d} / \mathrm{cm}^{2}$ & C. vicinus from Add my Pet database \\
\hline 'kappa_g1' & allocation fraction to soma & 0.9 & - & C. vicinus from Add my Pet database \\
\hline 'length_g1' & $\begin{array}{l}\text { (Volume-weighted) mean length } \\
\text { of the zooplankton box }\end{array}$ & 0.05 & $\mathrm{~cm}$ & $\begin{array}{l}\text { Assumed to be half of the adult size, } \\
\text { which is } \sim 1 \mathrm{~mm} \text { (Razouls et al., } \\
2005 \text { ). }\end{array}$ \\
\hline 'MinSTmp_g1' & $\begin{array}{l}\text { Minimum temperature for } \\
\text { spawning }\end{array}$ & 10 & ${ }^{\circ} \mathrm{C}$ & $\begin{array}{l}\text { Set to } 10^{\circ} \mathrm{C} \text { in order to avoid } \\
\text { spawning in winter }\end{array}$ \\
\hline 'rmorA_g1' & Mortality coef at $\mathrm{T}=20^{\circ} \mathrm{C}$ & 0.2 & $1 / \mathrm{d}$ & $\begin{array}{l}\text { As derived from mortality rate and } \\
Q_{10} \text { in Buitenhuis et al. }(2006)\end{array}$ \\
\hline 'rmorB_g1' & $\begin{array}{l}\text { Mortality coef for allometric } \\
\text { (length-dependent) relationship }\end{array}$ & 0 & - & $\begin{array}{l}\text { Set to } 0 \text { in order to disable length } \\
\text { dependency of mortality, as also } \\
\text { supported by Aksnes (1996). }\end{array}$ \\
\hline 'Pm_L3_g1' & $\begin{array}{l}\text { vol-specific somatic maintenance } \\
\text { at } \mathrm{T}=20^{\circ} \mathrm{C}\end{array}$ & 480 & $\mathrm{~J} / \mathrm{d} / \mathrm{cm}^{3}$ & C. vicinus from Add my Pet database \\
\hline Pr_MDIAT & $\begin{array}{l}\text { Food preference coefficient of } \\
\text { zooplankton for diatoms }\end{array}$ & 0.85 & - & $\begin{array}{l}\text { Food pref of meso-zooplankton for } \\
\text { diatoms (Daewel 2013) }\end{array}$ \\
\hline Pr_FLAGE & $\begin{array}{l}\text { Food preference coefficient of } \\
\text { zooplankton for flagellates }\end{array}$ & 0.5 & - & $\begin{array}{l}\text { Food pref for flagellates(Daewel } \\
\text { 2013) [average of coeff of micro- } \\
\text { and meso-zooplankton] }\end{array}$ \\
\hline
\end{tabular}




\begin{tabular}{|c|c|c|c|c|}
\hline Pr_DINOF & $\begin{array}{l}\text { Food preference coefficient of } \\
\text { zooplankton for dinoflagellates }\end{array}$ & 0.1 & - & $\begin{array}{l}\text { Food pref of meso-zooplankton for } \\
\text { flagellates (Daewel 2013) }\end{array}$ \\
\hline Pr_PHAEO & $\begin{array}{l}\text { Food preference coefficient of } \\
\text { zooplankton for phaeocystis }\end{array}$ & 0.3 & - & $\begin{array}{l}\text { Food pref of meso-zooplankton for } \\
\text { cyanobacteria (Daewel 2013) }\end{array}$ \\
\hline 'rSpawn_g1' & ultimate reproduction rate & 0.105 & $1 / \mathrm{d}$ & C. vicinus from Add my Pet database \\
\hline 'shape_g1' & shape coefficient & 0.3143 & - & $\begin{array}{l}\text { C. Vicinus from Add my Pet } \\
\text { database }\end{array}$ \\
\hline 'Ta_g1' & Arrhenius temp & 8000 & $\mathrm{~K}$ & $\begin{array}{l}\text { C. Vicinus from Add my Pet } \\
\text { database }\end{array}$ \\
\hline 'Tl_g1' & lower boundary tolerance range & 273 & $\mathrm{~K}$ & $\begin{array}{l}\text { C. Vicinus from Add my Pet } \\
\text { database }\end{array}$ \\
\hline 'Th_g1' & upper boundary tolerance range & 400 & K & $\begin{array}{l}\text { C. Vicinus from Add my Pet } \\
\text { database }\end{array}$ \\
\hline 'Tal_g1' & $\begin{array}{l}\text { Arrhenius temp for lower } \\
\text { boundary }\end{array}$ & 50000 & $\mathrm{~K}$ & $\begin{array}{l}\text { C. Vicinus from Add my Pet } \\
\text { database }\end{array}$ \\
\hline 'Tah_g1' & $\begin{array}{l}\text { Arrhenius temp for upper } \\
\text { boundary }\end{array}$ & 190000 & K & $\begin{array}{l}\text { C. Vicinus from Add my Pet } \\
\text { database }\end{array}$ \\
\hline 'TC_g1' & Grazer carbon content & 1.0 & - & $\begin{array}{l}\text { As based on zooplankton values } \\
\text { from the Delwaq-CONSBL module }\end{array}$ \\
\hline 'TN_g1' & Grazer nitrogen content & 0.1818 & - & $\begin{array}{l}\text { As based on zooplankton values } \\
\text { from the Delwaq-CONSBL module }\end{array}$ \\
\hline 'TP_g1' & Grazer phosphate content & 0.0263 & - & $\begin{array}{l}\text { As based on zooplankton values } \\
\text { from the Delwaq-CONSBL module }\end{array}$ \\
\hline 'TSi_g1' & Grazer silicate content & 0.0 & - & $\begin{array}{l}\text { As based on zooplankton values } \\
\text { from the Delwaq-CONSBL module }\end{array}$ \\
\hline 'Vp_g1' & $\begin{array}{l}\text { Volume start of reproductive } \\
\text { stage }\end{array}$ & $4.8 \mathrm{e}-06$ & $\mathrm{~cm}$ & $\begin{array}{l}\text { C. Vicinus from Add my Pet } \\
\text { database (structural mass at } \\
\text { puberty divided by the vol-spec } \\
\text { structural mass) }\end{array}$ \\
\hline 'Xk_g1' & half saturation coefficient & 0.04 & $\mathrm{gC} / \mathrm{m}^{3}$ & $\begin{array}{l}\text { Based on the half saturation } \\
\text { constant in Daewel (2013), } \\
\text { converted to units of } \mathrm{gC} / \mathrm{m}^{3}\end{array}$ \\
\hline 'Yk_g1' & $\begin{array}{l}\text { Half saturation coefficient for } \\
\text { negative effect of plastics on food } \\
\text { intake }\end{array}$ & $\begin{array}{l}0.3 \text { and } \\
0.15 \\
\text { (medium } \\
\text { and large } \\
\text { impact) }\end{array}$ & $\mathrm{gC} / \mathrm{m}^{3}$ & $\begin{array}{l}\text { Calibrated on basis of Cole et al. } \\
\text { (2013); this study }\end{array}$ \\
\hline
\end{tabular}




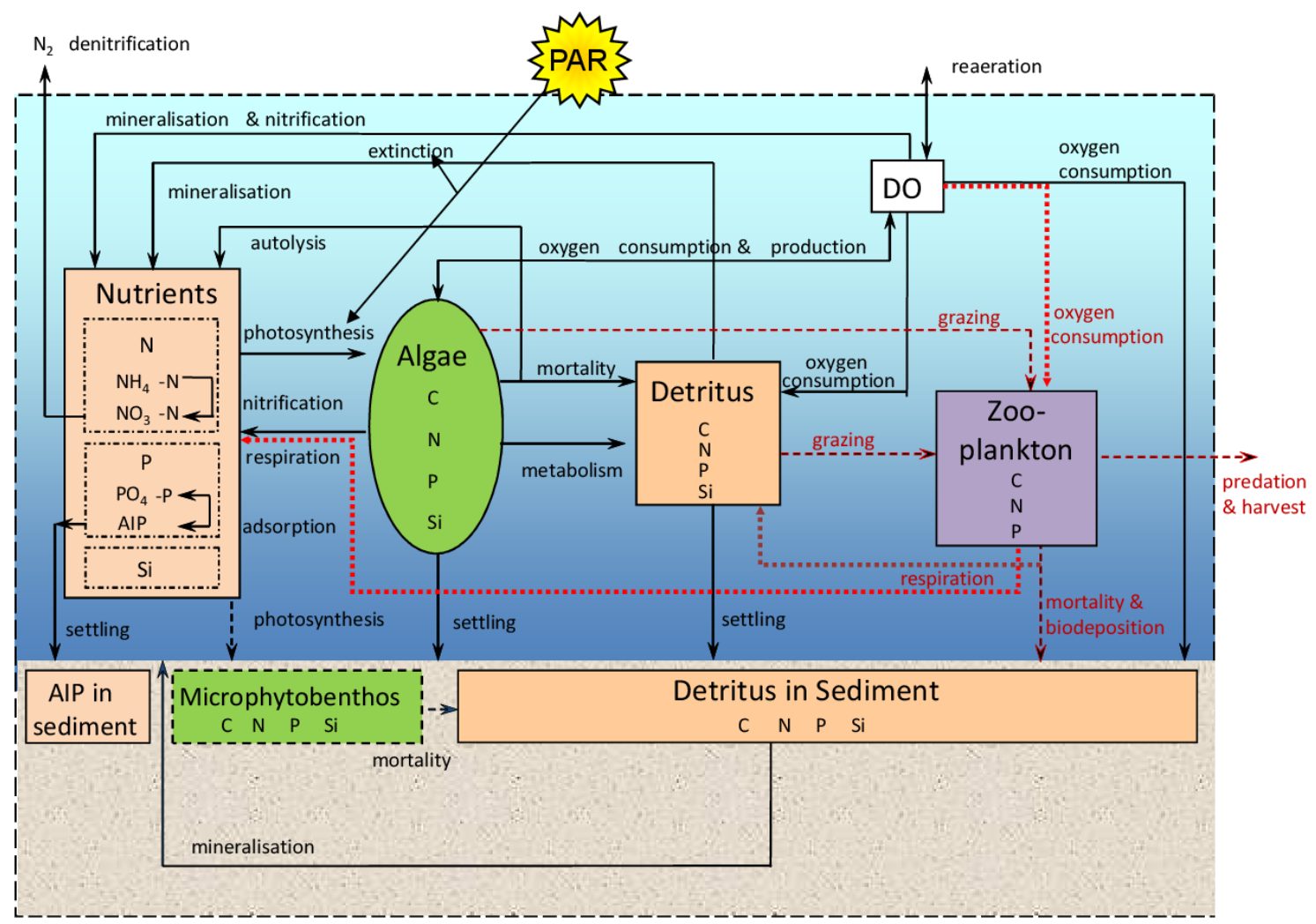

Fig 3. Diagram of the state variables and processes in the generic ecosystem model (Delft3D-GEM) as extended with an explicit zooplankton compartment. Boxes indicate the variables that can be explicitly calculated. Variables in the pelagic phase are inorganic nutrients (NH4 =ammonium; $\mathrm{NO}=$ nitrate; $\mathrm{P}=$ phosphate; $\mathrm{Si}=$ silicate; $\mathrm{AIP}=$ adsorbed inorganic phosphate), algae, detritus, and zooplankton (which are composed of variable ratios of $\mathrm{C}=$ carbon; $\mathrm{N}=$ nitrogen; $\mathrm{P}=$ phosphate and $\mathrm{Si}=$ silicate) and $\mathrm{DO}=$ dissolved oxygen; variables in the sediment are AIP, micrpohytobenthos and detritus. Arrows indicate how these variables are linked by biogeochemical processes; photosynthetically active radiation (PAR) has to be provided as input to the model. 


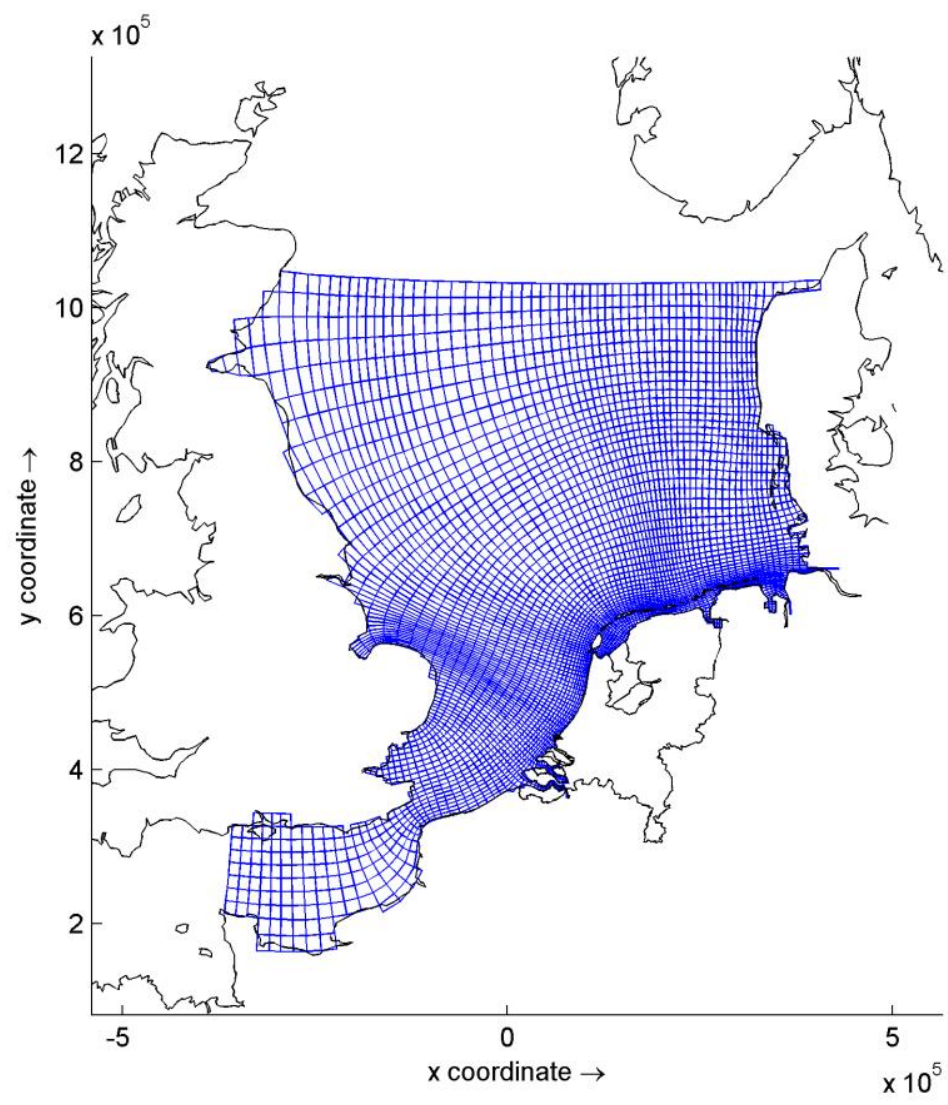

Fig 4. Model grid of the Delft3D-GEM for the Southern North Sea and the eastern part of the English Channel. Large cells $20 x 20 \mathrm{~km}$, small coastal cells $1 \times 1 \mathrm{~km}$. 


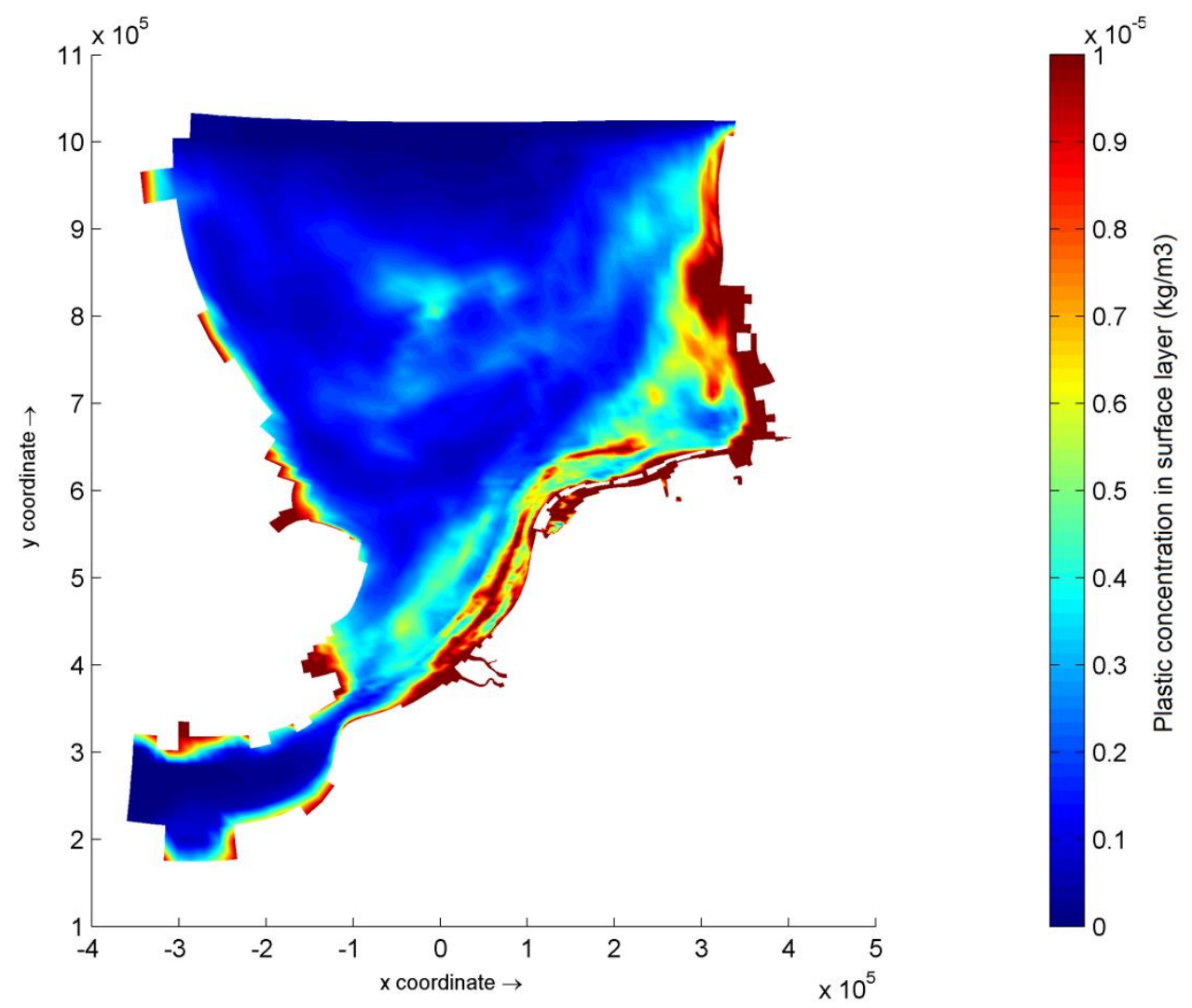

Fig 3. Annual average microplastic concentration $\left[\mathrm{kg} / \mathrm{m}^{3}\right]$ in the surface layer as described by the forcing function based on model results by Van Der Meulen et al. (2016 and 2014), Stuparu et al. (2015), and Pope (2015). 

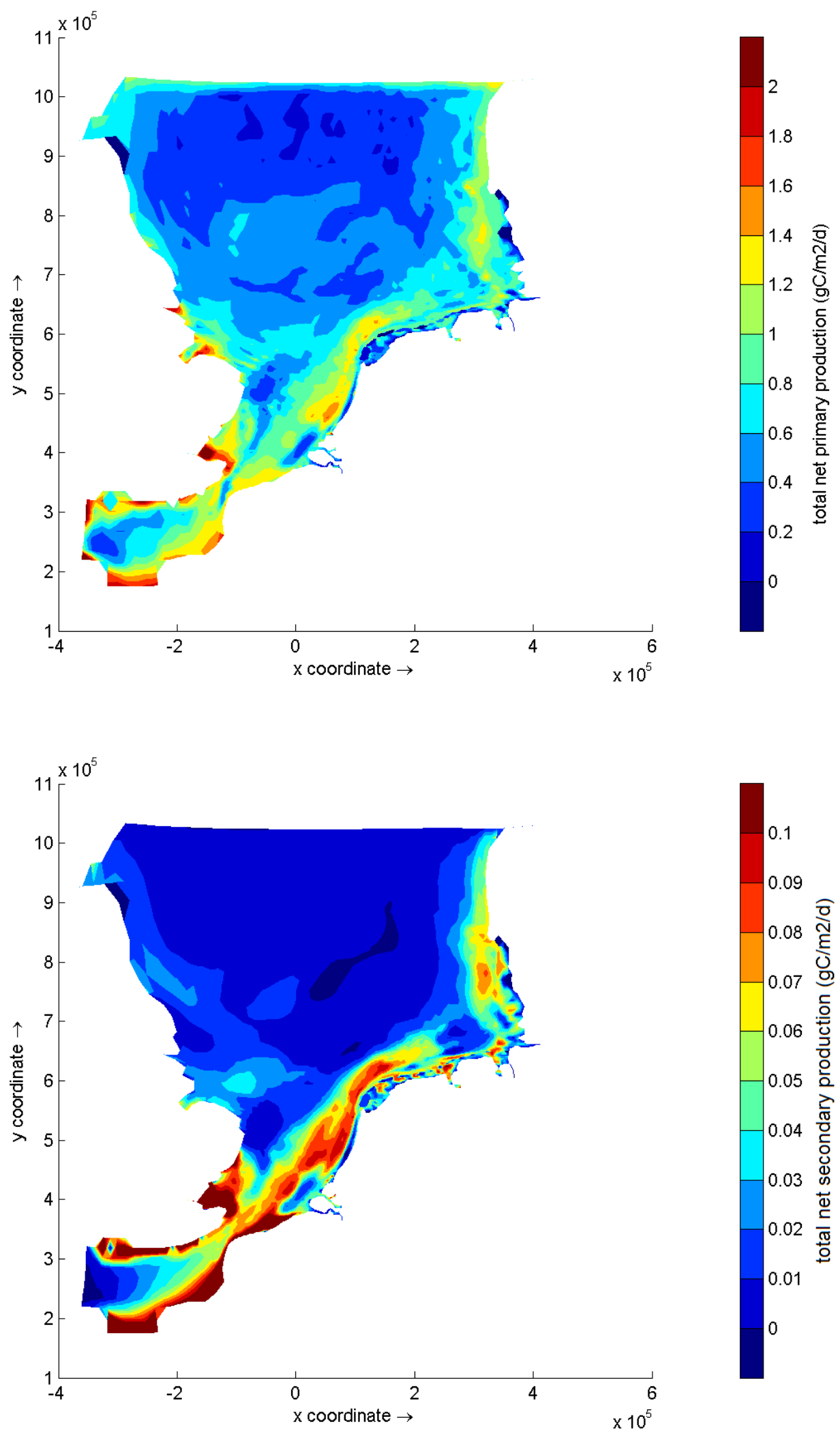

Fig 4. Annual average productivity in the southern North Sea. Shown are (A) primary productivity $\left[\mathrm{g} \mathrm{C} / \mathrm{m}^{2} / \mathrm{d}\right]$ and (B) secondary productivity $\left[\mathrm{g} \mathrm{C} / \mathrm{m}^{2} / \mathrm{d}\right]$ as modelled by the Delft3DGEM model for the North Sea. Note that colour scales differ between the two graphs. 

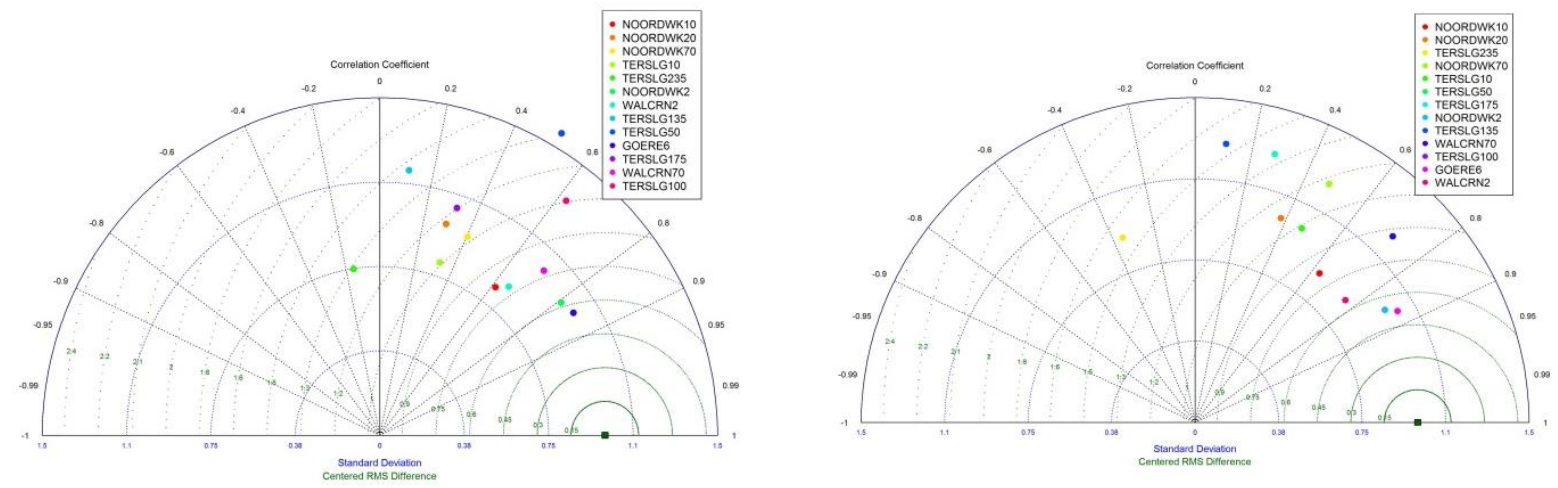

Fig 5. Comparison of model fit with and without including an explicit zooplankton compartment. Shown are Taylor diagrams for modelled chlorophyll concentrations against all available measured chlorophyll concentration data in 2008 for 13 locations in the Dutch part of the North Sea. The left frame shows model results without the zooplankton compartment, the right frame shows the same results when the zooplankton was taken into account. 

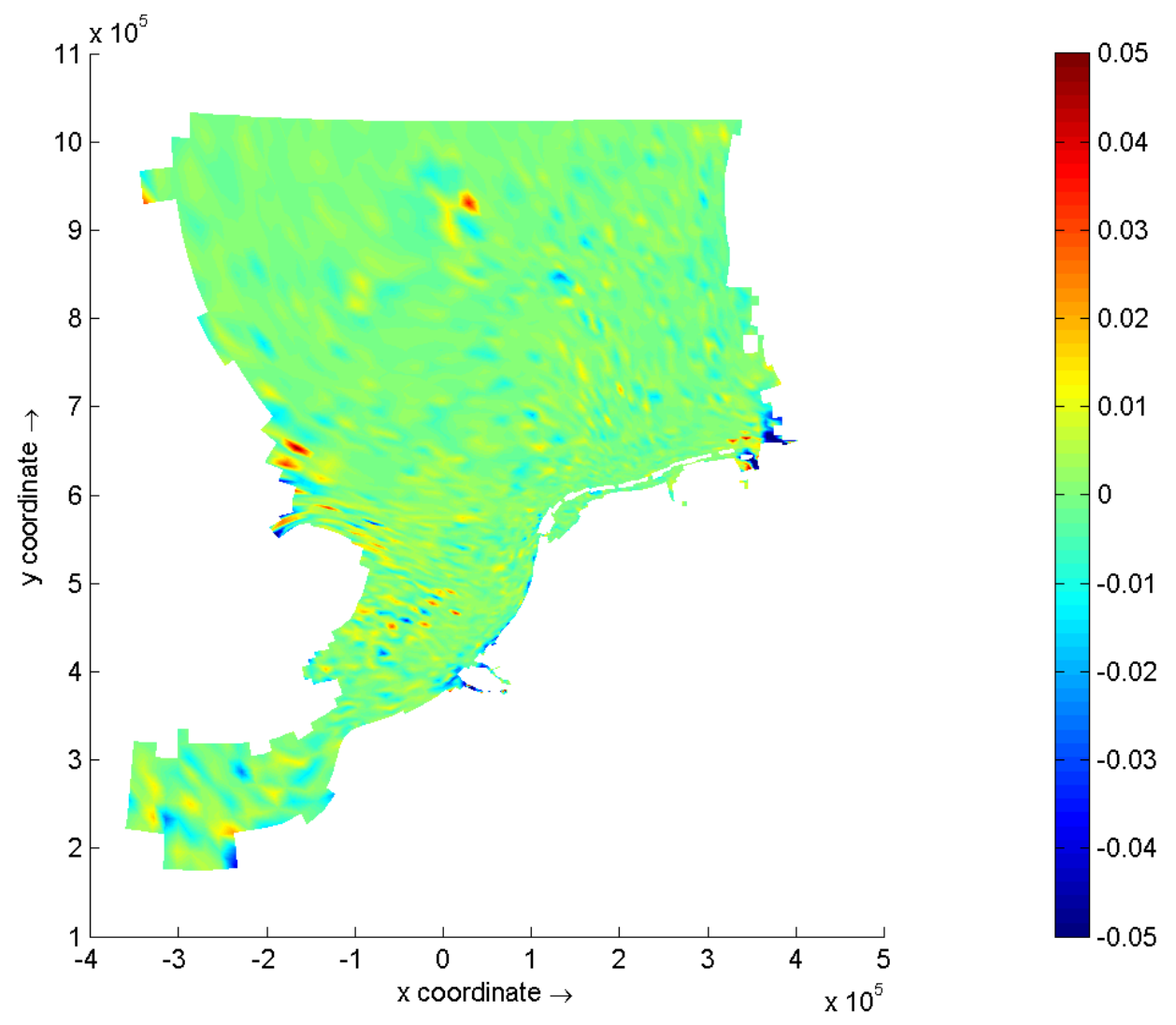

Fig 6. Modelled impact of microplastics on primary production. Shown is the relative change in the annual primary production [-] under the assumption that the nominal concentration of plastics in the experiment by Sjollema et al. (2016) is 100 times larger than the actual concentration that was measured in the experiment. 


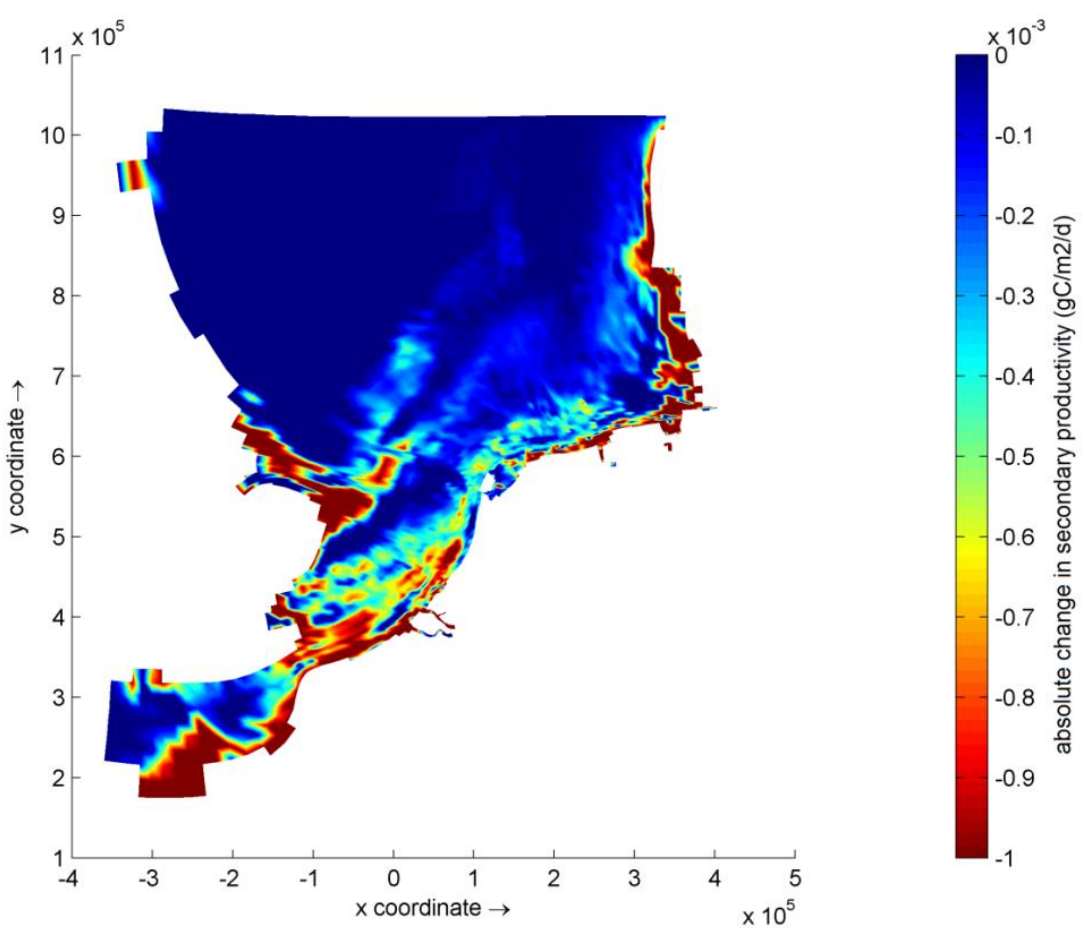

A

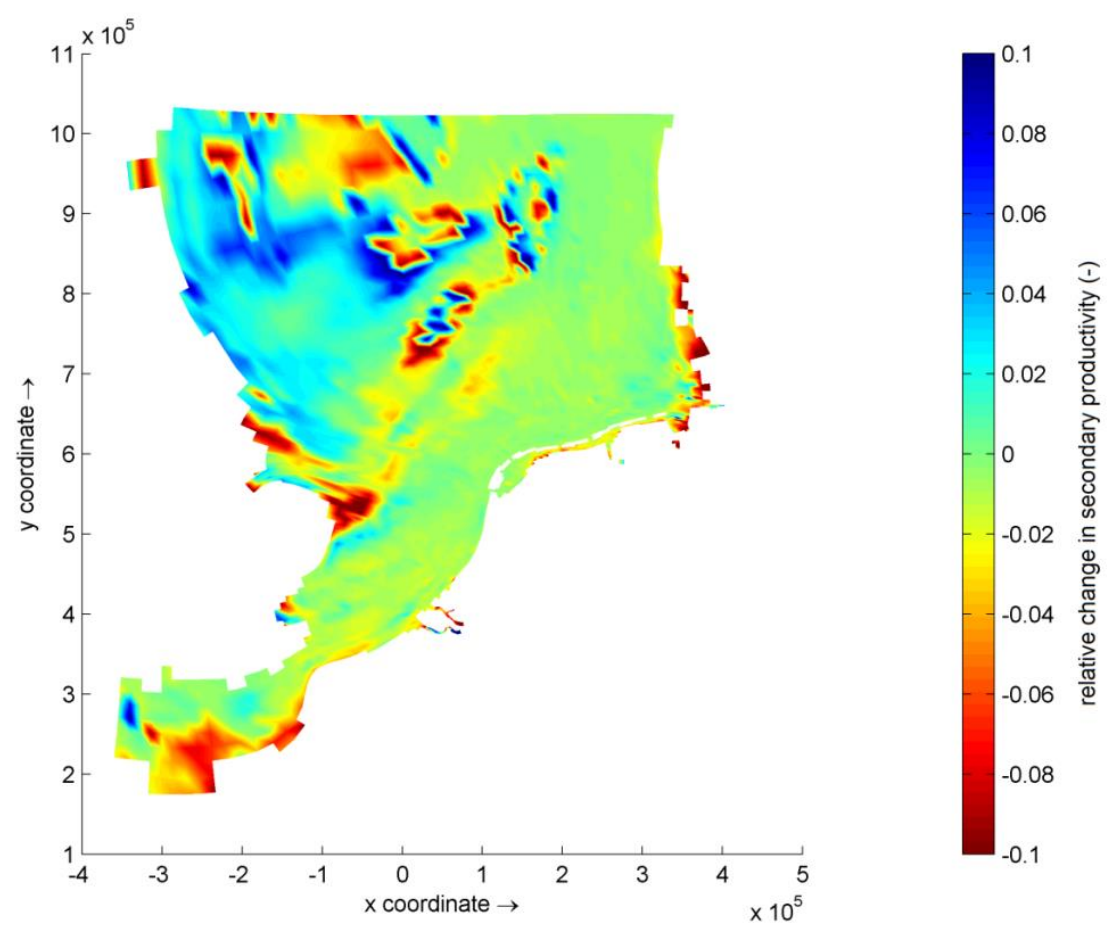

B

Fig 7. Modelled impact of microplastics on secondary productivity. Shown are the modelled changes in secondary productivity expressed in (A) absolute units $[\mathrm{g} \mathrm{C} / \mathrm{m} 2 / \mathrm{d}]$ and in (B) relative units [-]. 